\title{
Intraspecific variation in a physiological thermoregulatory mechanism: the case of the lizard Liolaemus tenuis (Liolaeminae)
}

\author{
Variación intraespecífica en un mecanismo termorregulatorio fisiológico: \\ el caso del lagarto Liolaemus tenuis (Liolaeminae)
}

MARCELA A. VIDAL ${ }^{1 *}$, JUAN CARLOS ORTIZ $^{1} \&$ ANTONIETA LABRA ${ }^{2}$

\author{
${ }^{1}$ Departamento de Zoología, Facultad de Ciencias Naturales y Oceanográficas, Universidad de Concepción, \\ Casilla 160-C, Concepción, Chile \\ ${ }^{2}$ Centre for Ecological and Evolutionary Synthesis (CEES), Department of Biology, University of Oslo, P.O. Box 1066 \\ Blindern, N-0316 Oslo, Norway; \\ *e-mail for correspondence: marvidal@udec.cl, marcela.vidal@gmail.com
}

\begin{abstract}
The interspecific variation of heating rates in Liolaemus lizards, suggests an adaptive value of this physiological thermoregulatory mechanism, which would allow lizards to cope with the environmental thermal restrictions, imposed to behavioral thermoregulation. This trend has barely been tested at intraspecific level, and here we explore if intraspecific variation in heating rates occurs in Liolaemus tenuis, a relative widely distributed species from central Chile. We test the hypothesis that heating rates are related to the thermal environmental conditions at which populations are exposed, by comparing the heating rates of three populations (from a latitudinal range), which inhabit under different thermal conditions. Additionally, we explore if the intrinsic factor, sex, also modulates heating rates. There was a significant intraspecific variation in heating rates, at population and gender level. These rates however, showed only a partial relationship with the environmental thermal conditions. We found that the northern population, inhabiting at higher temperature, heated slower, which might reduce the risk of overheating. On the other hand, independent of the population, females heated slower than males. The meaning of this sexual variation is unclear, but may be consequence of the significant differences in genders' social behavior. Because males defend a territory with a harem, by heating faster, they can allocate extra time in behaviors associated to the defense and maintenance of the territory.
\end{abstract}

Key words: Chile, geographic variation, sexual variation, thermoregulation.

\section{RESUMEN}

La variación interespecífica en las tasas de calentamiento de Liolaemus pareciera ser un mecanismo fisiológico adaptativo que permitiría a los lagartos enfrentar restricciones térmicas ambientales impuestas a la termorregulación conductual. Esta tendencia ha sido raramente analizada a nivel intraespecífico y en este estudio exploramos si existe variación intraespecífica en las tasas de calentamiento de Liolaemus tenuis, una especie con rango de distribución relativamente amplio en Chile central. Probamos la hipótesis de que las tasas de calentamiento están relacionadas con la condición térmica ambiental, a través de comparaciones de las tasas de calentamiento de tres poblaciones (a lo largo de un rango latitudinal), que habitan en ambientes térmicos diferentes. Además, exploramos si el factor intrínseco, sexo, modula estas tasas de calentamiento. Las tasas de calentamiento tienen una variación intraespecífica significativa a nivel poblacional y sexual. Sin embargo, estas tasas están solo parcialmente relacionadas a las condiciones ambientales a la que están sometidas las poblaciones. La población norteña, que habita a más altas temperaturas, se calienta más lento, lo que podría reducir el riesgo de sobrecalentamiento. Por otra parte, independiente de la población, las hembras se calientan más lento que los machos. El significado de esta variación sexual no es claro, pero podría ser consecuencia de las significativas diferencias en las conductas sociales de ambos sexos. Debido a que los machos defienden un territorio con un harén, un calentamiento más rápido les permitiría asignar mayor tiempo a las conductas asociadas a la defensa y mantención del territorio.

Palabras clave: Chile, variación geográfica, variación sexual, termorregulación. 


\section{INTRODUCTION}

Body temperature is the most significant physiological variable that affects ectotherms fitness, because it modulates mainly all their behavioral and physiological performances (Huey \& Stevenson 1979, Bennett 1980, Huey 1982, Atkinson 1994). Squamate reptiles, as other ectotherms, have evolved a high diversity of thermoregulatory mechanisms to cope with the heterogeneity in the thermal environments, allowing animals to attain and maintain adequate body temperatures (Labra \& Vidal 2003, Kiefer et al. 2007). The main type of thermoregulatory mechanisms is behavioral, e.g., changes in the daily activity patterns, or changes in the microclimate used to thermoregulate (e.g., Labra et al. 2001). Nevertheless, behavioral thermoregulation can be supported by physiological mechanisms, such as variations of the heating and cooling rates (e.g., Bartholomew 1982, Dzialowski \& O'Connor 1999); animals that live at lower temperatures tend to heat faster (e.g., Díaz et al. 1996). On the other hand, morphological mechanisms such as variations in color patterns can also help behavioral thermoregulation; animals living at lower temperatures tend to be darker, which would favor faster heating rates (Clusella-Trullas et al. 2007).

Interspecific variations in the heating rates of Liolaemus lizards can be consider an adaptive physiological thermoregulatory mechanism, to cope with restrictions imposed to behavioral thermoregulation, since species of the high altitude (lower temperature but higher radiation), heated slower (Carothers et al. 1997). Remarkable, this trend has barely been explored at intraspecific level, even considering that many Liolaemus species are widely distributed (Donoso-Barros 1966, Veloso \& Navarro 1988), and their populations are submitted to different thermal environments (e.g., Labra 1998, Ibargüengoytía \& Cussac 2002). The exception comes from the study that included two populations of L. fabiani, inhabiting different thermal environments; the population submitted to a lower environmental temperature showed faster heating rates (Labra et al. 2001), which in fact is opposed to what Carothers et al. (1997) found. To contribute to unravel the adaptive trends of the Liolaemus heating rates, here we explore the possibility that other Liolaemus species show intraspecific variation in heating rates, testing the hypothesis that populations submitted to lower environment temperatures have faster heating rates (e.g., Díaz et al. 1996, Labra et al. 2001). We measure heating rates in different populations (distributed across a latitudinal range) of a common species from central-south Chile, Liolaemus tenuis. This is a small lizard (adult snout-vent lengths range between 50 and $60 \mathrm{~mm}$ ), arboreal, with a wide geographic distribution, from sea level up to $1,800 \mathrm{~m}$, and from 31 to $39^{\circ} \mathrm{S}$ (Donoso-Barros 1966, Veloso \& Navarro 1988). On the other hand, Labra \& Bozinovic (2002) reported that the reproductive conditions affected the heating rates of two Liolaemus species from central Chile, $L$. monticola and L. fuscus. However, since it is unclear if the sex per se, and not the reproductive condition, affects physiological thermoregulation, our second aim is to determine if there is a sexual variation in the heating rates of L. tenuis.

\section{MATERIAL AND METHODS}

During spring-summer of 2001-2002 lizards were collected at different sites in Chile (Fig. 1, Appendix 1), although based on similarities of the localities thermal conditions we established three major populations: northern (semi-arid Mediterranean region), central (sub-humid Mediterranean region), and southern (humid Mediterranean region) (sensu di Castri 1968, Fig. 1). The annual mean maximal air temperature of each site was $21.8,19.7$, and 17 ${ }^{\circ} \mathrm{C}$, respectively (di Castri \& Hajek 1976). This type of thermal measurements, although broad, has been show to be a good predictor of the thermoregulatory physiology of Liolaemus (Labra 1998). Lizards were transported to the laboratory (Universidad de Concepción), and just before experiments they were weighted $( \pm$ $0.1 \mathrm{~g})$. Heating rates were measured in all individuals, as was previously described (Labra et al. 2001, Labra \& Bozinovic 2002). Briefly, lizards were affixed with tape to a pasteboard by their extremities, to prevent movements. They were cooled down in a freezer to a body temperature of $14{ }^{\circ} \mathrm{C}$. Thereafter, animals were placed in an incubator with still air (no thermal exchange by convection), at $37 \pm 0.5{ }^{\circ} \mathrm{C}$. 
During trials, a $\mathrm{Cu}$-constant thermocouple was inserted into the cloaca, and body temperatures were recorded every $30 \mathrm{sec}$, beginning when these were $15{ }^{\circ} \mathrm{C}$, and ended when they reached $35{ }^{\circ} \mathrm{C}$. Finally, heating rates were transformed into thermal time constants $(\operatorname{tau}=\tau)$. This was derived for the slope of a plot of $\mathrm{Ln}(\mathrm{Tb}-\mathrm{Ta})$ as a function of time, where $\mathrm{Tb}$ was the body temperature and $\mathrm{Ta}$ the air temperature $\left(37^{\circ} \mathrm{C}\right)$ : $\mathrm{b}=-0.4343 / \tau$ (Cossins \& Bowler 1987). At the end of experiments, lizards were sacrificed, fixed in alcohol $(70 \%)$, and deposited in the Museo de Zoología of Universidad de Concepción (see Appendix 1).

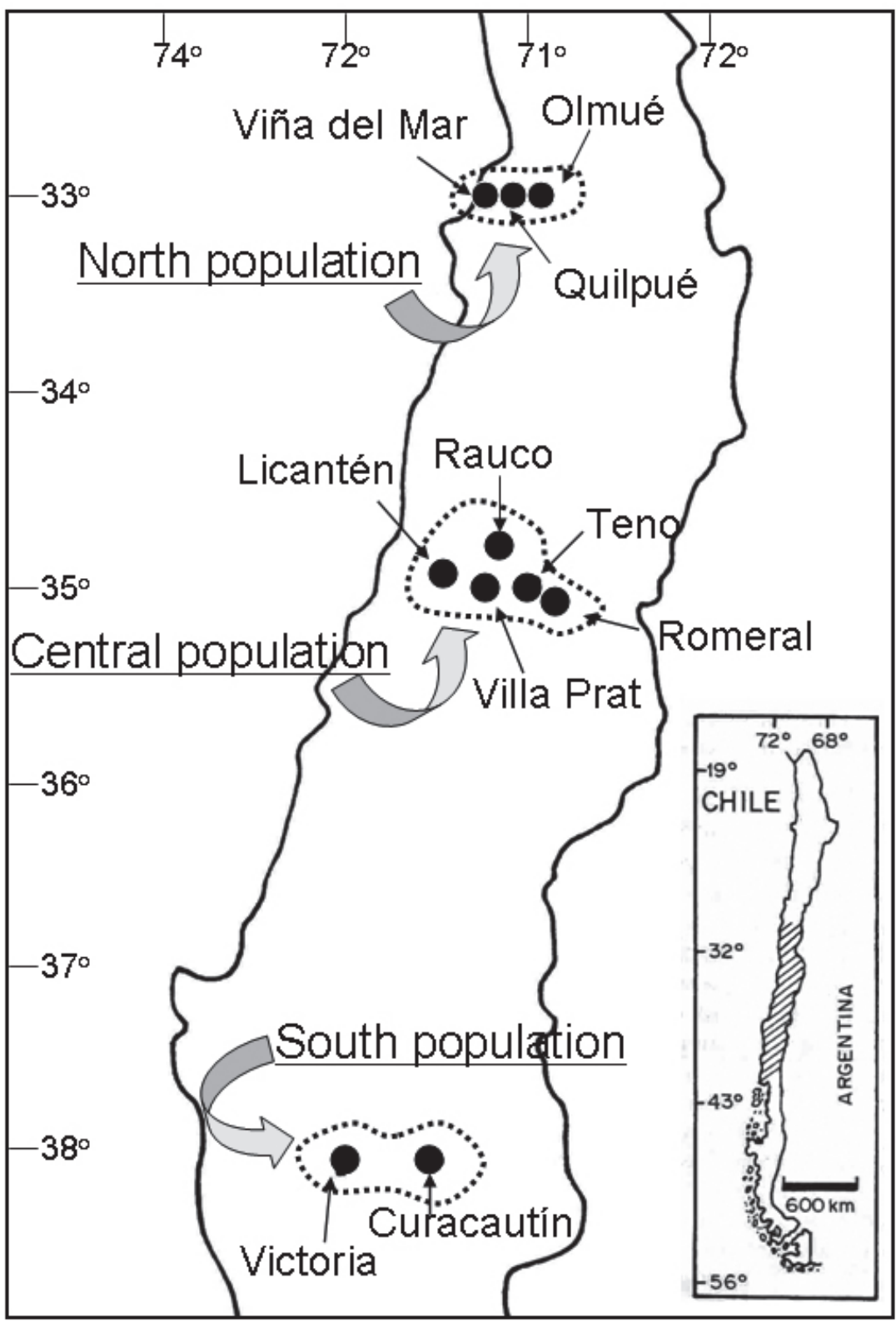

Fig. 1: Geographic location of the collecting sites of Liolaemus tenuis. Insert: distribution of $L$. tenuis in Chile. The main map corresponds to the dashed area of the complete Chilean map.

Localización geográfica de los sitios de colecta de Liolaemus tenuis. Inserto: distribución de L. tenuis en Chile. El mapa principal corresponde al área achurada del mapa de Chile completo. 
Analysis of the differences between sexes and population in weight was performed by two-way analysis of variance (ANOVA). Because body mass affects the speed of heat exchange (Carothers et al. 1997, Dzialowski \& O'Connor 2004), the effects of sex, population and their interactions upon heating rates was analyzed with a two-way ANCOVA with body mass as covariate, followed by Tukey test for multiple comparisons. One-way ANCOVAs were used to test initially intrapopulation homogeneity in heating rates.

\section{RESULTS}

The measurements of the body weight obtained for different populations and sexes are shown in Table 1, while the mean values of thermal time constants are shown in Fig. 2. Differences in body mass was detected between sexes $\left(F_{1,35}\right.$ $=6.17, \mathrm{P}=0.02)$, but no differences were found among populations $\left(\mathrm{F}_{2,35}=0.24 ; \mathrm{P}=\right.$ $0.79)$ and there was no effect of the interaction $\left(F_{2,35}=0.09, P=0.913\right)$. The three populations did not show significant intrapopulation differences in $\tau$ (northern: $\mathrm{F}_{2,25}=0.17, \mathrm{P}=$ 0.85; central: $\mathrm{F}_{2,20}=0.21, \mathrm{P}=0.92$; southern: $\left.\mathrm{F}_{2,25}=0.02, \mathrm{P}=0.89\right)$. However, L. tenuis showed a geographical variation in heating rates $\left(\mathrm{F}_{2,35}=28.31, \mathrm{P}=0.001\right)$; it was higher in the northern population than in the other two populations $(\mathrm{P}<0.001)$, and there were no differences in the heating rates between central and southern populations $(\mathrm{P}>0.05)$. On the other hand, there were sexual differences in heating rates. As is shown in Fig. 2, females heated slower than males $\left(\mathrm{F}_{1,35}=4.39, \mathrm{P}=\right.$
0.043 ), and this difference was independent of the population, since there was no effect of the interaction between sex and population upon heating rates $\left(\mathrm{F}_{2,35}=0.68, \mathrm{P}=0.51\right)$. Since interaction was not significant, we reanalyze $\tau$; two independent one-way ANCOVAs, with body mass as a covariable, were used to study the effects of sex and population. In both cases we obtained a significant effect of these factors (population: $\mathrm{F}_{2,35}=25.40, \mathrm{P}=0.001$; sex: $\mathrm{F}_{1,35}$ $=5.67, \mathrm{P}=0.024)$.

\section{DISCUSSION}

The heating rates of $L$. tenuis showed intraspecific variation, at population and sex level. Although measurements were obtained allowing lizards only the absorption of longwave radiation, this intraspecific variation in heating rates suggests that it may have an important role under natural conditions, particularly when lizards use thigmothermic thermoregulation. As in other Squamate (e.g., Gibson \& Falls 1979; Díaz et al. 1996, Labra et al. 2001) this variation may constitute an adaptation to cope with variations in the thermal constraints imposed to behavioral thermoregulation. The northern population, submitted to a higher environmental (e.g., substrate) temperature, heated slower, which may reduce the potential negative effects of inhabit at higher temperatures (i.e., overheating). Under the present experimental conditions, when individuals were impeded to conduct behavioral thermoregulation (e.g., heating rates measured in immobilized individuals), the likelihood that the northern

TABLE 1

Descriptive statistic (mean \pm standard error) of the snout-vent length (SVL, mm), and body mass (g) of male and female of Liolaemus tenuis from three populations; $\mathrm{n}=$ sample size

Estadística descriptiva (promedio \pm error estándar) de la longitud hocico-cloaca (SVL, mm) y masa corporal (g) de machos $\mathrm{y}$ hembras de Liolaemus tenuis provenientes de tres poblaciones; $\mathrm{n}=$ tamaño de muestra

\begin{tabular}{lccccc}
\hline Population & \multicolumn{2}{c}{ SVL } & & \multicolumn{2}{c}{ Body mass } \\
\cline { 2 - 3 } Northern & $50.65 \pm 1.23 \mathrm{n}=12$ & $50.07 \pm 1.25 \mathrm{n}=14$ & & $4.12 \pm 0.15 \mathrm{n}=12$ & $3.77 \pm 0.13 \mathrm{n}=14$ \\
Central & $47.57 \pm 2.01 \mathrm{n}=8$ & $49.29 \pm 1.02 \mathrm{n}=12$ & & $4.18 \pm 0.03 \mathrm{n}=8$ & $3.90 \pm 0.08 \mathrm{n}=12$ \\
Southern & $52.11 \pm 1.34 \mathrm{n}=10$ & $50.76 \pm 1.59 \mathrm{n}=15$ & & $4.16 \pm 0.23 \mathrm{n}=10$ & $3.71 \pm 0.15 \mathrm{n}=15$ \\
\hline
\end{tabular}


population overheated was lowered by $39 \%$. The plasticity of the heating rates in L. tenuis is also supported when is determined the differences in the thermal time constant between the northern population $(t=5.29 \pm$ 0.61 min, mean \pm SD) and the one reported for a L. tenuis' population from similar latitude but higher altitude $(\mathrm{t}=3.00 \pm 0.25 \mathrm{~min})$ (Labra \& Bozinovic 2002). However, this latter $t$ value is similar to the one measured in the southern population $(t=3.09 \pm 0.77 \mathrm{~min})$. Because, at higher altitudes Liolaemus are submitted to lower environmental temperature (Carothers et al. 1997), a faster heating rate may allow lizards, living at lower environmental temperatures (i.e., higher altitude and latitude), not to reduce dramatically their daily and annual activity period (Norris 1967). Nevertheless, under the assumption that heating rates of L.tenuis are adaptive, it is unclear why the central and southern populations were similar. Future studies are necessary to evaluate the possibility that the different populations differ in their physiological thermoregulatory responses when other radiative conditions are available e.g., short-wave radiation and use heliothermic thermoregulation (see Belliure \& Carrascal 2002). Additionally, populations may differ in other physiological mechanism, involved in thermoregulation, such as breathing patterns that, by bucopulmonar evaporation, can help to reduce the overheating possibilities (Tattersall et al. 2006).

Liolaemus tenuis not only has sexual dimorphism in morphology (Vidal et al. 2005) and coloration (Vidal et al. 2007), it also has sexual differences in the thermal physiology, as females showed slower heating rates than males. Presently, sexual variation in physiological thermoregulatory mechanisms in

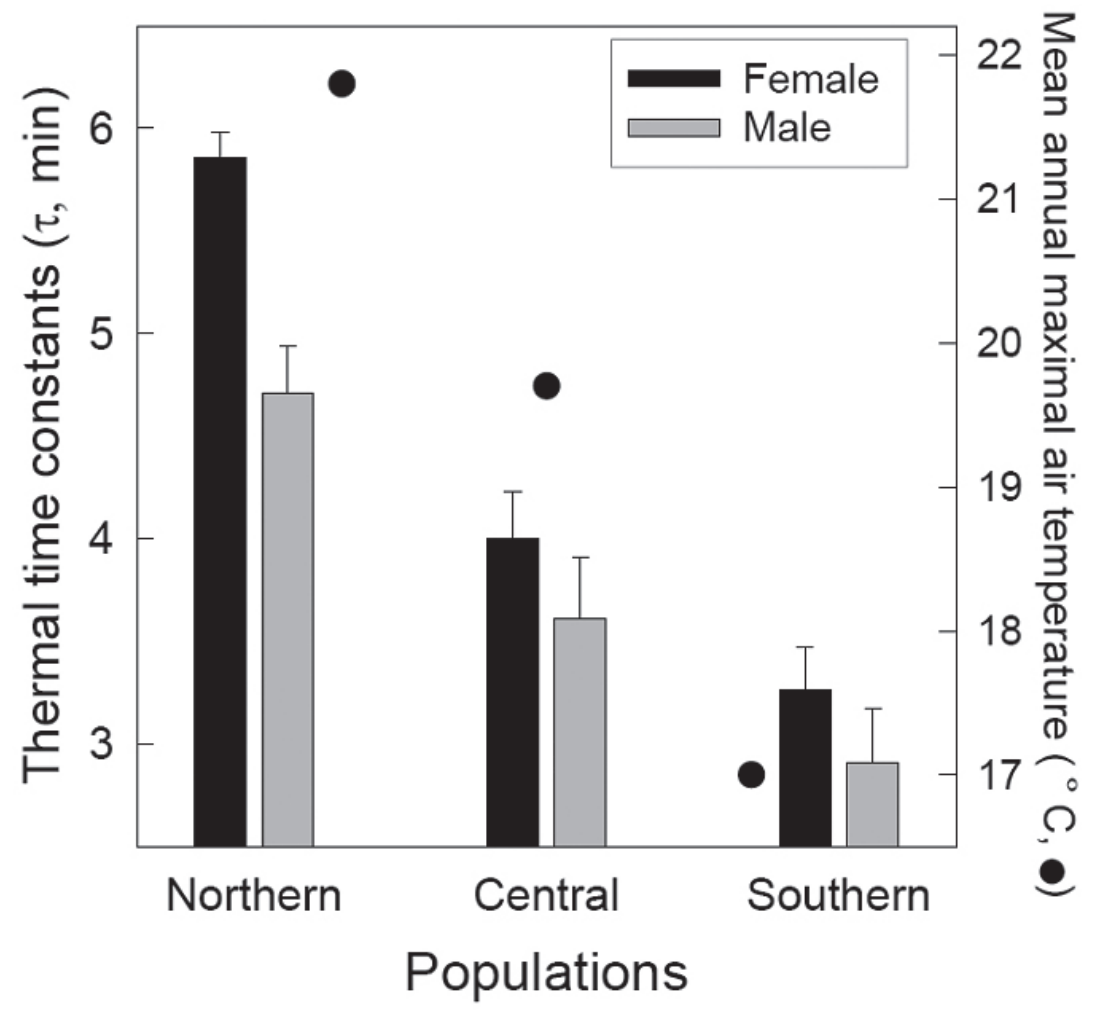

Fig. 2: Mean thermal time constants of males and females of Liolaemus tenuis from three populations distributed along a latitudinal range. Bars are means \pm standard error. Circles are the mean annual maximal air temperature where the different populations inhabit (di Castri \& Hajek 1976).

Promedio de las constantes de tiempo térmicas de machos y hembras de Liolaemus tenuis provenientes de tres poblaciones distribuidas a lo largo de un rango latitudinal. Las barras corresponden a los promedios \pm error estándar. Los círculos corresponden a la temperatura promedio anual máxima del ambiente en donde viven las diferentes poblaciones (di Castri \& Hajek 1976). 
lizards has been neglected. As far as we know for Squamate, there are only two reports indicating sexual differences in heat exchange. Fraser (1985) reported no sexual differences in the heating rates of Ergenia cunninghami, although males showed slower cooling rates than females. On the other hand, Ibargüengoytía (2005) reported that females of Phymaturus patagonicus had slower heating rates than males, as we found for L. tenuis. However, these authors did not give hypotheses to explain these sexual variations in heating exchange. We propose that these sexual differences in heating rates of $L$. tenuis may be consequence of differences in the social behavior of both sexes. Males are territorial and defend a harem (Manzur \& Fuentes 1979), exhibiting high levels of aggression during intrasexual interactions (Trigosso-Venario et al. 2002). Males, compared to females, can save about $15 \%$ of time during each heating event. Therefore, by warming faster males can reduce the time spent in behavioral thermoregulation, being able to allocate more time to defend and maintain their territories and harems. In addition, males will not be seriously impaired if they are forced continuously to have activities that keep them out of their preferred body temperatures (e.g., fights), as they can heat faster.

A well-documented factor that affects heating rates is skin color. Dark species or populations tend to be more abundant in environments with lower temperatures (Clusella-Trulla et al. 2007), because dark colors will favors faster heating (Norris 1967). Our measurements of heating rates in L. tenuis were not done with the aim to determine if color modulates these rates, as they were not measured under sunlight. However, it is noteworthy that the darkest sex (females) and population (northern) (Vidal et al. 2007), showed the corresponding slower heating rates. Thus, the combined information suggests that colors may not play a key role in L. tenuis' thermoregulation.

The exact mechanism that underlies the geographic and sexual variation in the heating rates of $L$. tenuis is unclear. It might be consequence of differences in the cardiovascular system, such as in the degree of vascularization and/or control of heart rate. Because an increase in the number of small vessels determines an increase in the rate of heat transfer (Seebacher 2000), we propose that males and females may differ in the skin vascularization, and males, and probably the central and southern populations, have a denser network of vessels in their surfaces. This also would favor males to regulate the color of their skin, as they, much more than females, show significant color change due to temperature (Donoso-Barros 1966). Males can start to exhibit their colorful bodies soon after they are active, behavior that may be important for males' social interactions (Vidal et al. 2007). Alternative, populations and/or sexes can have differences in their abilities to control heart rate, and eventually females and northern population can keep or have slower heart rates, which would determine slower heating rates (Seebacher 2000).

Finally, our results tend to support the hypothesis that populations submitted to a lower environmental temperatures show faster heating rates. However, the differences between the trends reported for the Liolaemus heating rates (Carothers et al. 1997, Labra et al. 2001, Labra \& Bozinovic 2002, this study), can be consequence of the use of different methodologies to determine these rates. Therefore, for a better comprehension of the factors that modulate Liolaemus heating rates, it is crucial to perform new experiments and determine among other, which is the effect of different heat transmission modes upon heating rates of Liolaemus species (Belliure \& Carrascal 2002).

\section{ACKNOWLEDGEMENTS}

Authors thanks to V. Jerez, R. Moreno, M. Fernández and R. Cifuentes by their invaluable assistance in the field; P. Sabat and two reviewers for helpful comments on an early version of the manuscript. This study was partly funded by FONDECYT 1980115 to JCO and 3990021 to AL.

\section{LITERATURE CITED}

ATKINSON D (1994) Temperature and organism size: a biological law for ectotherms? Advances in Ecological Research 25: 1-58.

BARTHOLOMEW GA (1982) Physiological control of 
body temperature. In: Gans C \& FH Pough (eds) Biology of Reptilia: 167-211. Academic Press, London, United Kingdom.

BELLIURE J \& LM CARRASCAL (2002) Influence of heat transmission mode on heating rates and on the selection of patches for heating in a Mediterranean lizard. Physiological and Biochemical Zoology 75: 369-376

BENNETT AF (1980) The thermal dependence of lizard behaviour. Animal Behaviour 28: 752-762.

CAROTHERS JH, SF FOX, PA MARQUET \& FM JAKSIC (1997) Thermal characteristics of ten Andean lizards of the genus Liolaemus in centra Chile. Revista Chilena de Historia Natural 70: 297. 309.

CLUSELLA-TRULLAS S, JH VAN WYK \& JR SPOTILA (2007) Thermal melanism in ectotherms. Journal of Thermal Biology 32: 235-245.

COSSINS AR \& K BOWLER (1987) Temperature biology of animals. Chapman and Hall, New York, New York, USA. 399 pp

DI CASTRI F (1968) Esquisse ecologique du Chili. In: Deboutteville D \& T Rapoport (eds) Biologie de 1'Amérique austral: 7-52. Edition du Centre National de la Recherche Scientifique, Paris, France.

DI CASTRI F \& ER HAJEK (1976) Bioclimatología de Chile. Vicerrectoría Académica de la Universidad Católica de Chile, Santiago, Chile. 128 pp.

DÍAZ JA, D BAUWENS \& B ASENSIO (1996) A comparative study of the relation between heating rates and ambient temperatures in lacertid lizards. Physiological Zoology 69: 1359-1383.

DONOSO-BARROS R (1966) Reptiles de Chile. Universidad de Chile, Santiago, Chile. $458 \mathrm{pp}$

DZIALOWSKI EM \& MP O'CONNOR (1999) Utility of blood flow to the appendages in physiological control of heat exchange in reptiles. Journal of Thermal Biology 24: 21-32.

DZIALOWSKI EM \& MP O'CONNOR (2004) Importance of the limbs in the physiological control of heat exchange in Iguana iguana and Sceloporus undulatus. Journal of Thermal Biology 29: 299-305.

FRASER S (1985) Variability of heating and cooling rates during radiant heating in a scincid lizard, Egernia cunninghami. Comparative Biochemistry and Physiology 80: 281-286.

GIBSON AR \& B FALLS (1979) Thermal biology of the common garter snake Thammnophis sirtalis L. II. The effects of melanism. Oecologia 43: 99-109.

HUEY RB (1982) Temperature, physiology and the ecology pf reptiles. In: Gans C \& FH Pough (eds) Biology of Reptilia: 25-91. Academic Press, London, United Kingdom.

HUEY RB \& RD STEVENSON (1979) Integrating thermal physiology and ecology of ectotherms: a discussion of approaches. American Zoology 19: 357-366.

IBARGÜENGOYTÍA NR \& VE CUSSAC (2002) Body temperatures of two viviparous Liolaemus lizard species, in Patagonian rain forest and steppe. Herpetological Journal 12: 131-134.
IBARGÜENGOYTÍA NR (2005) Field, selected body temperature and thermal tolerance of the syntopic lizards Phymaturus patagonicus and Liolaemus elongatus (Iguania: Liolaemidae). Journal of Arid Environments 62: 435-448.

KIEFER MC, M. VAN SLUYS \& C.F.D. ROCHA (2007) Thermoregulatory behaviour in Tropidurus torquatus (Squamata, Tropiduridae) from Brazilian coastal populations: an estimate of passive and active thermoregulation in lizards. Acta Zoologica 88: 81-87.

LABRA A (1998) Selected body temperatures of seven species of Chilean Liolaemus lizards. Revista Chilena de Historia Natural 71: 349-358.

LABRA A \& F BOZINOVIC (2002) Interplay between pregnancy and physiological thermoregulation in Liolaemus lizards. Ecoscience 9: 421-426.

LABRA A \& MA VIDAL (2003) Termorregulación en reptiles: un veloz pasado y un futuro lento. In: Bozinovic F (ed) Fisiología ecológica y evolutiva. Teoría y casos de estudio en animales: 207-224. Ediciones Universidad Católica de Chile, Santiago, Chile.

LABRA A, M SOTO-GAMBOA \& F BOZINOVIC (2001) Behavioral and physiological thermoregulation of Atacama desert-dwelling Liolaemus lizards. Ecoscience 8: 413-420

MANZUR MI \& ER FUENTES (1979) Polygyny and agonistic behavior in the tree-dwelling lizard Liolaemus tenuis (Iguanidae). Behavioral Ecology and Sociobiology 6: 23-28.

NORRIS KS (1967) Color adaptation in desert reptiles and its thermal relationship. In: W. W. Mistead (ed) Lizards ecology, a symposium: 162-229. University of Missouri Press, Columbia, Missouri, USA.

SEEBACHER F (2000) Heat transfer in a microvascular network: the effect of heart rate on heating and cooling in reptiles (Pogona barbata and Varanus varius). Journal of Theoretical Biology 203: 97109.

TATTERSALL GJ, V CADENA \& MC SKINNER (2006) Respiratory cooling and thermoregulatory coupling in reptiles. Respiratory Physiology \& Neurobiology 15: 302-318.

TRIGOSSO-VENARIO R, A LABRA \& HM NIEMEYER (2002) Interactions between males of the lizard Liolaemus tenuis: roles of familiarity and memory. Ethology 108: 1-8.

VELOSO A \& J NAVARRO (1988) Lista sistemática y distribución geográfica de anfibios y reptiles de Chile. Bolletino del Museo Regionale de Scienze Naturale (Italy) 6: 481-539.

VIDAL MA, JC ORTIZ, CC RAMÍREZ \& M LAMBOROT (2005) Intraspecific variation in morphology and sexual dimorphism in Liolaemus tenuis (Tropiduridae). Amphibia-Reptilia 26: 343351.

VIDAL MA, JC ORTIZ \& A LABRA (2007) Sexual and geographic variation of color patterns in Liolaemus tenuis (Squamata, Liolaeminae). Gayana (Chile) 71: $27-33$ 


\section{APPENDIX 1}

List of the individuals of Liolaemus tenuis, with their geographic coordinates (latitude, longitude, altitude), used in this study and deposited in the herpetological collection of the Museo de Zoología of Universidad de Concepción, Chile (MZUC):

Listado de los individuos de Liolaemus tenuis, con sus coordenadas geográficas (latitud, longitud, altitud), utilizados en este estudio y depositados en la colección herpetológica del Museo de Zoología de la Universidad de Concepción, Chile (MZUC):

Northern group: Olmué $\left(33^{\circ} 00^{\prime} \mathrm{S}, 71^{\circ} 12^{\prime} \mathrm{W}\right.$, 139 m): MZUC27109-119; Quilpué (3302' $\mathrm{S}$, $\left.71^{\circ} 26^{\prime} \mathrm{W}, 128 \mathrm{~m}\right)$ : MZUC27130-136; Viña del

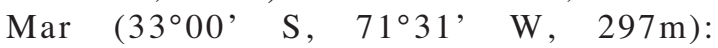
MZUC27091-092. Central group: Licantén (345' ' S, 72 00 ' W, 65 m): MZUC27011-017; Rauco $\left(34^{\circ} 55^{\prime} \mathrm{S}, 71^{\circ} 19^{\prime} \mathrm{W}, 172 \mathrm{~m}\right)$ : MZUC27017-023; Romeral (34⒌' S, $71^{\circ} 07^{\prime}$
W, 395 m): MZUC27027-029; Teno (3452' S, 71 $\left.{ }^{\circ} 10^{\prime} \mathrm{W}, 252 \mathrm{~m}\right)$ : MZUC27103-105; Villa Prat $\left(35^{\circ} 04^{\prime} \mathrm{S}, 71^{\circ} 37^{\prime} \mathrm{W}, 211 \mathrm{~m}\right)$ : MZUC26978-983; Southern group: Curacautín $\left(38^{\circ} 25^{\prime} \mathrm{S}, 71^{\circ} 52^{\prime} \mathrm{W}, 541 \mathrm{~m}\right)$ : MZUC27064077; Victoria $\left(38^{\circ} 13^{\prime} \mathrm{S}, 72^{\circ} 19^{\prime} \mathrm{W}, 334 \mathrm{~m}\right)$ : MZUC27053-063. 